\title{
Atopic Dermatitis: Collegium Internationale Allergologicum (CIA) Update 2019
}

\author{
Dagmar Simon $^{\mathrm{a}}$ Andreas Wollenberg $^{\mathrm{b}}$ Harald Renz $^{\mathrm{c}}$ Hans-Uwe Simon $^{\mathrm{d}, \mathrm{e}}$ \\ ${ }^{a}$ Department of Dermatology, Inselspital, Bern University Hospital, University of Bern, Bern, Switzerland; \\ ${ }^{b}$ Department of Dermatology and Allergy, Ludwig Maximilian University of Munich, Munich, Germany; \\ 'Institute of Laboratory Medicine, Philipps University of Marburg, Marburg, Germany; ${ }^{d}$ Institute of Pharmacology, \\ University of Bern, Bern, Switzerland; ' ${ }^{\circ}$ Department of Clinical Immunology and Allergology, Sechenov University, \\ Moscow, Russia
}

\section{Keywords}

Atopic dermatitis - Anti-inflammatory therapy .

Comorbidities · Epithelial barrier · T-helper-2 inflammation

\begin{abstract}
Atopic dermatitis (AD) is a chronic inflammatory skin disease presenting with recurrent eczematous lesions and intense pruritus. It is common and affects both children and adults, often beginning in infancy. Due to the unpredictable disease course, its visible skin lesions, itching and scratching followed by sleeplessness, other associated atopic diseases, and behavioral and psychiatric disorders, AD is an immense burden for patients and caregivers. AD is determined by a genetic predisposition characterized by an impaired skin barrier and a T-helper-2-predominant inflammation. Restoration of the skin barrier is the main approach for treating and preventing AD. In order to cope with acute flares, usually topical corticosteroids (TCS) are applied, while topical calcineurin inhibitors $(\mathrm{TCl})$ are used mainly for maintenance therapy. There is a small group of patients who are refractory to TCS and TCl and require systemic immunosuppressive drugs such as ciclosporin. Novel, target-
\end{abstract}

ed therapies are under clinical investigation, among which an anti-IL-4/IL-13 receptor antibody has recently been approved in several countries. As we learn to understand the pathomechanisms of $A D$, the characteristics of the different patient subgroups, and the effectiveness of various targeted therapies, a personalized treatment ensuring the best efficacy and safety and, probably, a disease-modifying effect will result.

(c) 2019 S. Karger AG, Basel

Eczematous lesions, intense pruritus, and a relapsing disease course, as well as associated atopic diseases in the personal or family history, are the characteristics of atopic dermatitis (AD), a common chronic inflammatory skin disease. $\mathrm{AD}$ affects approximately $20 \%$ of all children at age 6 years and 5\% of adults in Western industrialized countries $[1,2]$. The development of AD is based on a genetic predisposition that determines both the skin barrier function and the predominant T-helper-2 (Th2)-type in-

Edited by: D.Y. Wang, Singapore.

\section{KARGER}

(c) 2019 S. Karger AG, Basel

E-Mail karger@karger.com

www.karger.com/iaa
Dr. Dagmar Simon

Department of Dermatology, Inselspital

Freiburgstrasse 34

$\mathrm{CH}-3010$ Bern (Switzerland)

E-Mail Dagmar.simon@insel.ch 
flammatory reaction. In addition, environmental factors may trigger $\mathrm{AD}$ by further affecting the skin barrier and inflammation. Th2-type cytokines have been shown to further impair the epidermal barrier. Thus, irritants and allergens may penetrate into the epidermis and perpetuate the inflammation. Moreover, in over $80 \%$ of $\mathrm{AD}$ patients, the skin is colonized by Staphylococcus aureus which can further harm the barrier and stimulate immune responses, thus initiating and perpetuating inflammation [3].

There is increasing evidence that several subtypes of AD exist. This observation might have implications for finding therapeutic approaches toward a personalized medicine. In this review, we will discuss the different facets of $\mathrm{AD}$ and the therapeutic strategies.

\section{Clinical Presentation}

\section{Phenotypes}

In infants, oozing and crusting eczematous lesions are found on the face and scalp but also on exterior sites on the extremities and trunk, sparing the diaper area. In children, adolescents, and adults, all body areas, but especially the cubital and popliteal folds, can be affected by AD. In addition to acute inflamed skin during exacerbations, dyshidrotic lesions, lichenification, and pruritic papules and nodules are characteristic clinical presentations. $\mathrm{AD}$ is the main risk factor for the development of hand eczema, one of the most common occupational diseases [4-6]. The clinical presentation may vary between ethnic groups, as Asian patients tend to have well-circumscribed, nummular lesions and lichenification, while involvement of the extensor sites and papules, a perifollicular distribution, or lichen planus-like lesions are seen mainly in dark-skinned patients $[7,8]$.

Colonization with $S$. aureus is a common finding in AD. Compared to the noncolonized, S. aureus-colonized $\mathrm{AD}$ patients have more severe $\mathrm{AD}$, higher blood eosinophil numbers, and higher total and allergen-specific IgE levels, as well as a greater barrier dysfunction as assessed by a transepidermal water loss and stratum corneum (SC) integrity that are not associated with filaggrin mutations [9].

Both the eczema area and severity index (EASI) and the objective scoring $\mathrm{AD}$ (SCORAD) index are validated tools for measuring disease severity [10]. A patient-oriented SCORAD (PO-SCORAD) for patient use has been validated [11] and is recommended for use in a routine setting [12].

\section{Pruritus}

Itch is the most striking and disturbing symptom of AD. Although scratching might reduce the itch and give brief relief, the resulting skin irritation and excoriations lead to a perpetuation of the inflammation associated with pruritus, and a vicious circle develops. Recent research has demonstrated that pruritus is generated by direct stimulation of nerve fibers as a result of the impaired barrier and via cytokines and neuropeptides released by inflammatory and resident cells [13]. Various pruritogens and their receptors, proteases and protease-activated receptor (PAR) 2 are involved in pruritus. Histamine may induce pruritus by activating $\mathrm{H} 1$ and $\mathrm{H} 4$ receptors and inhibiting $\mathrm{H} 3$ receptor on skin-specific sensory nerves [14]. IL-31 that is produced by T cells and granulocytes such as eosinophils and mast cells, and which binds to its receptor on peripheral nerve fibers, has been shown to link inflammation and pruritus in the skin [1517]. The observation that IL-31 induces an outgrowth of primary small-diameter dorsal root ganglia expressing abundant IL-31 receptor might explain the increased numbers of nerve fibers in AD skin and the sensitivity to minimal stimuli which induce itch in patients with $\mathrm{AD}$ $[18,19]$.

\section{Prevalence and Disease Course}

In a European birth cohort study, the prevalence of $\mathrm{AD}$ symptoms was between 11.4 and $16.9 \%$ during the first 6 years of age [2]. Children with an early onset (age $<2$ years) of $\mathrm{AD}$, especially those with persistent symptoms, had a significantly higher risk of associated food allergy and asthma, while the late-onset phenotype (age $>2$ years) was associated with allergic rhinitis [2]. In Europe, as shown for Bavaria/Germany, the $\mathrm{AD}$ prevalences of $12.4 \%$ in 1995 and $11.1 \%$ in 2002 have remained stable over the last decade, whereas a significant increase in eczema prevalence has been observed in Africa (i.e., 11.8\% in 1995 vs. $19.4 \%$ in 2002) [20]. The International Study of Asthma and Allergies in Childhood (ISAAC) revealed a great variation in the prevalence of current eczema in the age group $6-7$ years, ranging from $0.9 \%$ in India to $22.5 \%$ in Ecuador. Furthermore, it identified Latin America and Southeast Asia as new areas with an emerging high prevalence [21].

Although the skin lesions may improve over time, AD persists in up to $60 \%$ of patients, while a smaller percentage of patients (i.e., $18 \%$ after the 20 th year of life) develop first symptoms as adults [22]. According to an international, cross-sectional, web-based survey, the point prevalence among an adult population of self-reported 
patients ever having had an AD diagnosis by a physician was $4.9 \%$ in the USA, $3.5 \%$ in Canada, $4.4 \%$ in the EU, and $2.1 \%$ in Japan [1].

\section{Comorbidities of $A D$}

In addition to the atopic diseases allergic rhinitis and asthma, several other mainly neuropsychiatric disorders have been found to be associated with $\mathrm{AD}[23,24]$.

The AD-immanent pruritus leads to sleep disturbances in children and adults correlating with disease severity $[25,26]$. Moreover, infant eczema with concurrent sleeping problems has been predictive of emotional and behavioral problems at 10 years of age [27]. There is an association of $\mathrm{AD}$ and attention deficit/hyperactivity disorder (ADHD), in particular in children with sleep problems [28]. Interestingly, the significantly higher levels of ADHD symptoms in children with $\mathrm{AD}$ compared to healthy controls seem to be linked to the previous use of antihistamines [29]. A systematic review revealed an association between autism spectrum disorders and $\mathrm{AD}$, even though the authors stated somewhat inconsistent results due to variability in the study population and design, and the presence of other risk factors acting as confounding factors [30]. An increased risk of depression has been noted in both adolescents and adults affected with $\mathrm{AD}$ $[23,31]$. AD patients have a significantly higher frequency of suicidal ideation, anxiety, and depression compared to healthy controls $[32,33]$. A recent study showed that prenatal maternal depression and anxiety promote the risk of $\mathrm{AD}$ in offspring and suggested chronic stress, abnormal steroid levels, and reactive oxygen species as underlying mechanisms [34].

The prevalence of cardiovascular diseases is markedly lower in patients with $\mathrm{AD}$ compared to those with psoriasis [35]. A study determining the association between $\mathrm{AD}$ and cardiovascular events in the USA revealed that $\mathrm{AD}$ was not independently associated with nonfatal MI or stroke [36]. Based on recent studies, lifestyle factors associated with severe AD are likely to explain the apparent increased risk of cardiovascular disease [35-38]. A systematic literature review showed a slightly increased risk of lymphoma in patients with AD. Confusion between severe $\mathrm{AD}$ and cutaneous $\mathrm{T}$-cell lymphoma may account for this correlation, though topical corticosteroids (TCS) and topical calcineurin inhibitors (TCI) do not seem to play a role [39].

\section{The Burden of $A D$}

Patients report immense negative effects of $\mathrm{AD}$ on their quality of life correlating with severity and inade- quate control of the disease [40]. In addition to anxiety, depression, and sleep disorders, patients with $\mathrm{AD}$ report higher rates of mental and physical disturbances, work absenteeism, and activity impairment compared to non$\mathrm{AD}$ controls [31].

The direct and indirect costs of $\mathrm{AD}$ are huge when considering direct health care, including emergency department visits and hospitalization of patients with severe $\mathrm{AD}$ and/or infections (e.g., impetiginization and eczema herpeticum, costs of therapy including skin care, patient education, sick leave, job change or loss, and occupational insurance support) [41, 42].

\section{Pathogenenic Mechanisms}

Recent research has provided compelling evidence that epidermal barrier structure and function and cutaneous inflammation, as well as their interactions, play a role in the pathogenesis of $\mathrm{AD}$ (Fig. 1).

\section{Genetics}

Twin and family studies have shown that the predisposition to atopic disease is highly heritable. Atopic diseases, notably $\mathrm{AD}$, in either the mother or the father are significantly associated with eczema in the offspring, with the strongest association (OR 4.70; 95\% CI 2.648.37) when both the father and the mother report eczema [43]. According to a population-based, twin study, genetic predisposition accounted for $82 \%$ and nonshared environmental factors accounted for $18 \%$ of the individual susceptibility to developing AD [44]. The strongest known risk factors are null mutations of the filaggrin (FLG) gene, resulting in epidermal barrier deficiency [45].

A recent genome-wide association study reported 4 loci that achieved genome-wide significance for AD. These were: the epidermal differentiation complex (EDC) on chromosome 1 , the genomic region proximal to LRRC32 on chromosome 11, the RAD50/IL13 locus on chromosome 5, and the major histocompatibility complex on chromosome 6 [46]. So far, 31 risk loci for AD have been identified, and most susceptibility loci are related to (auto-)immune regulation, in particular, innate signaling and T-cell activation [47]. Moreover, genomewide association studies have revealed that asthma, hay fever, and eczema share 136 risk variants in 99 loci that dysregulate the expression of immune-related genes [48].

Current research focuses on epigenetic effects in $\mathrm{AD}$. Recently, an association of prenatal tobacco smoking and 


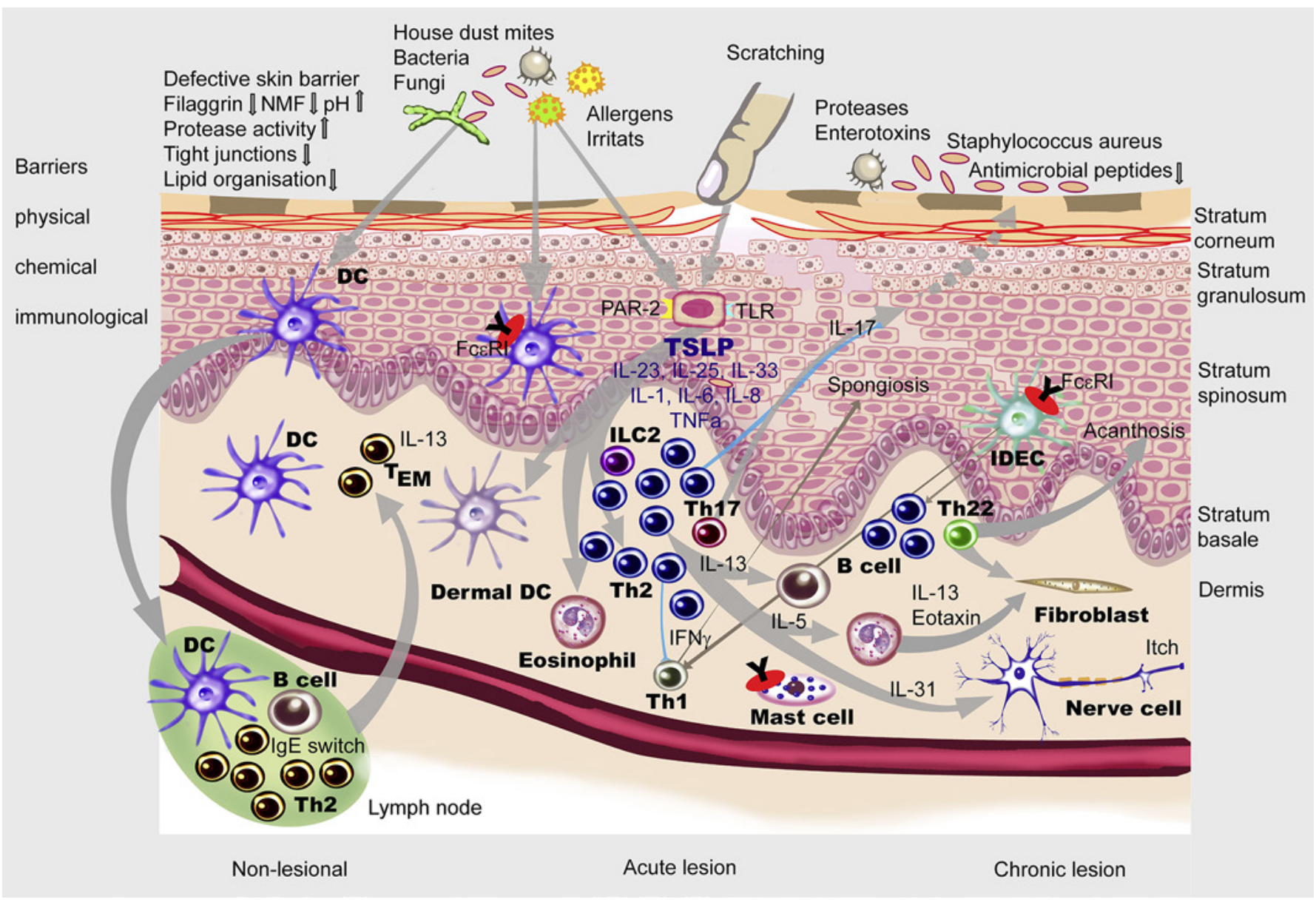

Fig. 1. Skin barrier dysfunction and inflammation in AD. Nonlesional skin already exhibits structural and functional barrier defects. Epidermal dendritic cells (DC) recognize pathogens penetrating the defective epidermal barrier and migrate to the regional lymph node where they prime naive T cells toward Th2 cells and $\mathrm{B}$ cells to produce IgE. Upon activation via TLR and PAR-2, keratinocytes release cytokines including TSLP and IL-33, driving T cells and innate lymphocytic cells (ILC) to produce type- 2 cytokines and thus initiating an acute inflammation. IL-5, IL-13, and

the innate immune response, specifically the regulation of nucleotide-binding oligomerization and pyrin domain containing-receptors (NLRP) owing to changes in NLRP2 promoter methylation and transcription, have been reported [49].

\section{Skin Barrier Dysfunction in AD Patients}

The epidermis provides a physical, chemical, and immunological barrier mainly involving the SC, the tight junction proteins in the stratum granulosum, and epidermal dendritic cells [50]. Abnormalities of the epidermal barrier are associated with typical clinical features of $\mathrm{AD}$
IL-31 stimulate B cells, eosinophils, mast cells, and nerve cells. Epidermal DC and IDEC, both bearing the high-affinity IgE receptor (FcERI), recognize allergens penetrating the defective barrier and enhance Th2 and Th1 inflammation. Th2 cytokines block the IL17-induced production of antimicrobial peptides and keratinocyte differentiation and enhance the barrier disruption. Th1 cells are thought to be involved in the development of spongiosis, while Th22 cells promote acanthosis and remodeling in chronic lesions.

such as dry and rough skin, low hydration, high transepidermal water loss, and an increase in $\mathrm{pH}$ [51]. In particular, low levels of filaggrin and natural moisturizing factor correlate with structural alterations as assessed by atomic force microscopy [52]. A deficiency of filaggrin, an essential structural protein of the SC, results in impaired keratin filament aggregation in the corneocytes, impaired lamellar body secretion, and decreased tight junction expression, corneodesmin density, and natural moisturizing factor production, as well as an elevated $\mathrm{pH}$ with subsequent enhanced protease activity [53]. Loss-of-function mutation in genes encoding filaggrin which are known to 
cause ichthyosis vulgaris also predispose to $\mathrm{AD}[45,54]$. Notably, most AD patients do not carry any filaggrin mutation, and not all carriers of filaggrin mutations develop $\mathrm{AD}[55,56]$. Besides a genetic disposition, Th2 cytokines such as IL-4 and IL-13 [57] and IL-33 [58] have been shown to reduce filaggrin expression. A deficiency of filaggrin might affect the differentiation of keratinocytes [59], the expression of tight junction proteins [60], endogenous protease activity [61], and TSLP production [62]. Other factors that have been associated with a defective epidermal barrier in $\mathrm{AD}$ are an altered lipid organization and ceramide composition with an increase in the proportion of short-chain ceramides in the context of Th2 inflammation [63-66]. Furthermore, an imbalance of protease inhibitors, e.g., reduced LEKTI expression, and proteases resulting in a high activity of both endogenous and exogenous proteases with subsequent PAR 2 activation and increased TSLP production, is thought to contribute to $\mathrm{AD}$ pathogenesis [67-70]. In addition to the SC, tight junctions formed by complex multiprotein structures are an important component of the skin barrier as they regulate the paracellular passage of water, ions, and solutes [71]. High levels of tight junction proteins have been shown to correspond to maximal barrier function for intermediate-sized molecules and macromolecules [72]. In AD patients, a functionally relevant, reduced expression of claudins that inversely correlate with Th2 markers has been observed, suggesting that impaired tight junctions contribute to the barrier dysfunction [73]. Moreover, both staphylococci proteases and the house dust mite allergen Der f1 which, exert cysteine protease activity, may abrogate the epidermal barrier $[74,75]$.

An insufficient skin barrier permits environmental factors including allergens, microbes, and their products to enter the epidermis where they are recognized by epidermal dendritic cells. In AD skin, Langerhans cells bear the high-affinity IgE receptor and, upon recognizing allergens which are known to cause immediate type reactions, may initiate T-cell responses [76, 77]. In addition to Langerhans cells, lesional skin and nonlesional AD skin harbor a distinct population of CD1a+ cells called inflammatory dendritic cells (IDEC) which bear even more high-affinity IgE receptors than Langerhans cells [78]. Recently it has been demonstrated that activated Langerhans cells extend dendrites through the tight junctions supposedly to capture antigens from the outside, while IDEC are localized in the lower part of the epidermis $[79,80]$. Antigens may also be recognized by keratinocytes via Toll-like receptors (TLR), e.g., dsRNA by

AD: CIA Update 2019
TLR 3 [81], S. aureus products by TLR2/TLR-6 [82], house dust mites by TLR1/6 [83], PAR 2 [84], and pattern recognition receptor NOD2 [85]. Keratinocytes activated by pathogens or mechanical injury release Th2-driving cytokines such as TSLP $[82,86]$, IL-25 [83], and IL-33 [87], as well as the proinflammatory cytokines IL-6, IL-8, and TNF- $\alpha$ [88].

\section{Predominant Th2 Inflammation}

Clinically unaffected (nonlesional) skin of AD patients already shows epidermal barrier defects and harbors a mild inflammation characterized by T cells, mainly Th2 cells, increased expression of the high-affinity IgE receptor, and an inflammatory cytokine milieu with prominent IL-13 expression $[89,90]$. Dendritic cells take up antigens entering through the defective epidermal barrier and then migrate to the regional lymph nodes where they prime $\mathrm{T}$ cells. Among these, the CLA+ memory/effector T cells shown to produce IL-13 may reenter the skin [91]. Cytokines and chemokines released by keratinocytes and dendritic cells upon antigen exposure stimulate T cells resident in the skin as well as innate lymphoid cells that in turn produce an armada of mainly Th2 cytokines, with subsequent proliferation, recruitment, and activation of inflammatory cells such as T cells, B cells, eosinophils, and mast cells [79, 87, 92-97]. Recent research has indicated that IL-13 is a key cytokine in AD inflammation, as it is involved in inducing pruritus and remodeling [98], activating eosinophils [99], regulating IgE synthesis [100], and promoting epicutaneous sensitization [101]. IL-33 produced by keratinocytes may also stimulate group 2 innate lymphoid cells that produce abundant Th2 cytokines including IL-5 and IL-13 [102]. In addition to Th2 responses, Th1, Th17, and Th22 cells and their corresponding cytokines have been detected in $\mathrm{AD}$ skin, suggesting possible roles, e.g., in evoking spongiosis [103], for the induction of antimicrobial peptide production [104] or in stimulation of epidermal hyperplasia and remodeling $[105,106]$. Interestingly, Asian AD patients have been reported to exhibit a distinct phenotype with Th2 skewing and Th17 polarization [8]. Also early-onset $\mathrm{AD}$ in children is characterized by significant Th17/Th22 skewing in addition to the Th2 inflammation of the skin [107].

\section{Interdependency of $\mathrm{S}$. aureus and $A D$}

The impaired epidermal barrier has been associated with $S$. aureus colonization and eczema herpeticum in patients with AD [108]. During acute flares, the microbial diversity significantly decreases, correlating with AD se- 
verity, while the proportion of S. aureus increases [109]. Early colonization with commensal staphylococci at age of 2 months has been observed to lower the risk of $\mathrm{AD}$ at 1 year [110]. Both dysbiosis and S. aureus promote inflammation in AD [111]. Various mechanisms have been reported via which $S$. aureus can contribute to $\mathrm{AD}$ pathogenesis, such as damage to keratinocytes and barrier structures, e.g., by proteases and toxins, stimulation of TLR on keratinocytes, the release of toxins acting as superantigens resulting in massive $\mathrm{T}$-cell stimulation, and the initiation of IgE production and mast cell activation $[112,113]$. Colonization with toxigenic $S$. aureus has been found to lead to a shift in the intradermal T-cell receptor $\mathrm{V} \beta$ repertoire that corresponds to the respective superantigen-responsive T-cell subsets and correlates with disease severity in $\mathrm{AD}$ children [114]. In infants, the presence of $S$. aureus on the skin at 3 months has been found to correlate with later development of AD [115]. Notably, the prevalence of $S$. aureus has been found to be increased at the onset of $\mathrm{AD}$ and already 2 months before an outbreak [115].

\section{$A D$ and the Atopic March}

$\mathrm{AD}$ is frequently associated with other atopic diseases such as allergic rhinitis and bronchial asthma. Moreover, food allergy, oral allergy syndrome, and eosinophilic esophagitis are commonly associated with $\mathrm{AD}$ [116]. There is evidence that the skin might be the starting point of the atopic march, i.e., (1) mutations in filaggrin, a key barrier protein, have been reported to be associated with severe eczema and bronchial asthma as well as food allergy $[117,118]$, and (2) epicutaneous sensitization to proteins (food and pollen) paves the way for developing food allergy and airway allergic diseases [119-121].

In $80 \%$ of $\mathrm{AD}$ patients, IgE sensitization is observed; however, 20\% do not have elevated serum IgE or positive skin prick test reactions [122]. Interestingly, significantly higher IgE levels have been found in male patients compared to females [22]. Atopy signs and concomitant atopic diseases are significantly more likely to be present in patients with an early onset and a chronic persisting course [22].

\section{Food Allergy in AD Patients}

IgE sensitization to food allergens (milk, eggs, fish, peanut or soy, and wheat) seems to be a common phenomenon in children and is not increased in children with $\mathrm{AD}$ compared to healthy controls [123]. In $14.8 \%$ of children with $\mathrm{AD}$, food hypersensitivity could be confirmed by oral food challenge tests [123], while others re- port a rate of approximately $30 \%$ in patients with refractory moderate to severe $\mathrm{AD}[124,125]$. In adults with $\mathrm{AD}$, food allergy as assessed by positive skin prick test results and history occurs in $10 \%$ of cases [126]. In addition to IgE-mediated reactions, there is evidence that allergenspecific $\mathrm{T}$ cells are responsible for food allergen-associated exacerbations of $\mathrm{AD}[127,128]$. Allergies to milk, eggs, and wheat typically resolve during childhood, whereas allergies to peanuts, tree nuts, fish, and shellfish are regarded as persistent [129]. In adults with AD sensitized to pollen, e.g., birch pollen, related foods should be considered as possible triggers of $\mathrm{AD}$ [130].

The observation that higher environmental peanut allergen levels are associated with an increased risk of peanut sensitization and allergy in children with FLG-null mutations or AD strongly suggests that sensitization occurs through the skin $[131,132]$. In contrast, early oral exposure to food allergens as shown for peanut and eggs seems to lower the risk of allergy specifically to these foods $[133,134]$.

\section{Therapeutic Management of AD}

Based on the pathophysiology of $\mathrm{AD}$, i.e., the impaired skin barrier and chronic inflammation, the treatment of $\mathrm{AD}$ is very complex $[135,136]$.

\section{Restoring the Skin Barrier}

To avoid dry skin and restore the barrier function, $\mathrm{AD}$ patients should regularly apply a basic topical therapy with emollients. Based on a Cochrane review and vast clinical experience, the application of moisturizers leads to an improvement in $\mathrm{AD}$ severity, increases the effect of anti-inflammatory therapies, reduces the number of flares, and decreases the use of TCS [137]. Would it be possible to prevent $\mathrm{AD}$ by restoring the skin barrier? In 2 studies, the effect of daily use of emollients in infants at high risk for atopy was studied, and indeed a significantly decreased relative risk of $\mathrm{AD}$ in the first 6 months of life was demonstrated $[138,139]$.

\section{Anti-Inflammatory Therapy}

In order to reduce skin inflammation and subsequent itch, TCS and TCI are applied. Usually, TCS are used to cope with acute exacerbations, while TCI are applied in subacute eczema as maintenance therapy and to sensitive areas of skin such as the face $[135,136]$. A proactive therapy with long-term, intermittent application of TCS and TCI is clinically effective for flare prevention [140]. Re- 
cent studies have shown that TCI are safe even when used for long-term therapy $[141,142]$. The routine of topical therapy requires time and effort, as well as steadiness and special skills by the patient. Accordingly, patients profit from educational programs $[143,144]$.

In some patients, these therapeutic measures might not be sufficient to control moderate to severe AD despite an optimized treatment plan and adherence to the treatment regimen. As a further step, immunosuppressive and immunomodulating drugs such as ciclosporin, methotrexate, azathioprine, and mycophenolate mofetil have been recommended in order to reduce disease-relevant inflammatory cell numbers and cytokine expression [145]. As these immunosuppressive drugs might affect blood cell numbers and function, immune responses, liver and kidney function, and blood pressure, their use is limited in certain patients and should be carefully monitored. Alitretinoin can be applied for severe hand eczema, including atopic eczema [146]. As an alternative, UV therapy is eligible to treat moderate to severe $\mathrm{AD}$; however, its accessibility is limited $[135,136]$.

\section{Toward a Targeted Therapy for AD}

Currently, a number of new substances and monoclonal antibodies that inhibit specific cytokines, cytokine receptors, intracellular signal transduction pathways or enzymes involved in $\mathrm{AD}$ pathogenesis are under clinical investigation. Dupilumab, a monoclonal human antibody targeting the shared IL-4/IL-13 receptor- $\alpha$ chain and thus blocking the action of IL-13 and IL-4, has already been approved for the treatment of AD in the USA and Europe. The application of $300 \mathrm{mg}$ dupilumab qw or $\mathrm{q} 2 \mathrm{w}$ results in rapid improvement of clinical signs and symptoms; among patients with moderate to severe $\mathrm{AD}$, up to $85 \%$ reach EASI-50, 44-51\% reach EASI-75, and $30-36 \%$ achieve EASI-90 after 16 weeks, while the frequency of pruritus decreases by $40-60 \%$ [147, 148]. Dupilumab has a sustained effect over 1 year and a tolerable safety profile, with conjunctivitis as a noteworthy adverse event occurring in $14-19 \%$ of patients [149]. Recent published phase 2 studies have demonstrated that the monoclonal antibodies that block IL-13 (lebrikizumab and tralokinumab) are effective in patients with moderate to severe AD [150, 151]. By applying fezakinumab, an anti-IL-22 antibody, a significant decline in disease severity scores (SCORAD, affected body surface area, and investigator global assessment), could be achieved and a pathogenic role for IL-22 in AD could be demonstrated [152]. Notably, therapy with ustekinumab that inhibits the common p40 subunit of IL-12/IL-23 and thus the production of IL-17, IL-21, and IL-22, was not effective in patients with moderate to very severe $\mathrm{AD}$ $[153,154]$. A 12-week therapy with nemolizumab, the anti-IL-31 receptor antibody, was shown to dramatically reduce pruritus and in parallel improve clinical signs of $\mathrm{AD}$ in a phase 2 study underlining the role of the itchscratch cycle [155].

The use of small molecules such as Janus kinase (JAK) inhibitors follows a different approach as compared to biologicals, since they block the intracellular signal transduction upon activation of cytokine receptors, e.g., by IL-2, IL-4, IL-7, IL-9, IL-13, IL-15, and IL-21 and interferon- $\gamma$. The first promising results have been reported with the topical application of tofacitinib achieving an EASI mean percentage change from baseline of $82 \%$ in the tofacitinib group compared to $30 \%$ in the placebo group [156]. Upon therapy with an oral JAK inhibitor, the percentage of patients achieving EASI-50 was significantly higher in the group treated with baricitinib plus TCS compared to the group given placebo plus TCS [157]. Currently, phase 2 and 3 studies with bariticinib and other JAK inhibitors are underway [158].

A promising option for treating $\mathrm{AD}$ is inhibition of phosphodiesterase 4 , a critical regulator of intracellular cyclic adenosine monophosphate levels that is expressed within inflammatory cells including $\mathrm{T}$ lymphocytes and eosinophils [158]. In 2 identically designed studies, more crisaborole- than vehicle-treated patients achieved investigator's static global assessment (ISGA) success (clear/ almost clear with $\geq 2$-grade improvement) [159].

\section{Unmet Needs and Outlook}

Despite the fact that $\mathrm{AD}$ is a chronic disease and that patients in remission will retain the $\mathrm{AD}$ predisposition lifelong, the prospects for treating and managing the disease are bright. Still, there is a list of unmet needs, in particular with respect to treatment and prevention of the disease as follows:

1. To develop therapies that specifically target pathogenically relevant mechanisms. There is immense progress in developing novel anti-inflammatory drugs; however, the problem of finding an effective and durable restoration of the skin barrier needs to be solved;

2. to identify biomarkers in order to better classify subgroups of $\mathrm{AD}$ patients with respect to treatment response and to monitor efficacy and safety of therapy - this requires the implementation of novel technologies in dermatological practice; 
3. to find effective methods to prevent $\mathrm{AD}$ or at least delay its onset, and to modify the disease course and the atopic march;

4. to better study the interdependency of AD and its comorbidities and develop strategies to recognize and treat them early; and

5. to raise broad social awareness of the medical, psychological, and economic burden of $\mathrm{AD}$ and to guarantee support for $\mathrm{AD}$ patients.

As we learn to better understand the pathogenic mechanisms, we may be able to treat and modify the disease course of $\mathrm{AD}$ as well as the development of other atopic/ allergic diseases even in the near future. The recently acquired knowledge on comorbidities will help immediately with their identification and provide appropriate medical and psychological assistance for AD patients. Novel targeted therapies now promise to act specifically on key players in the pathogenesis of $\mathrm{AD}$, to be effective and safe, and to enable personalized medicine.

\section{Disclosure Statement}

The authors have no conflict of interests to declare.

\section{References}

1 Barbarot S, Auziere S, Gadkari A, Girolomoni G, Puig L, Simpson EL, et al. Epidemiology of atopic dermatitis in adults: results from an international survey. Allergy. 2018 Jun;73(6): 1284-93.

2 Roduit C, Frei R, Depner M, Karvonen AM, Renz H, Braun-Fahrländer C, et al.; the PASTURE study group. Phenotypes of Atopic Dermatitis Depending on the Timing of Onset and Progression in Childhood. JAMA Pediatr. 2017 Jul;171(7):655-62.

3 Mempel M, Lina G, Hojka M, Schnopp C, Seidl HP, Schäfer T, et al. High prevalence of superantigens associated with the egc locus in Staphylococcus aureus isolates from patients with atopic eczema. Eur J Clin Microbiol Infect Dis. 2003 May;22(5):306-9.

4 Visser MJ, Verberk MM, Campbell LE, McLean WH, Calkoen F, Bakker JG, et al. Filaggrin loss-of-function mutations and atopic dermatitis as risk factors for hand eczema in apprentice nurses: part II of a prospective cohort study. Contact Dermat. 2014 Mar;70(3): 139-50.

5 Grönhagen C, Lidén C, Wahlgren CF, Ballardini N, Bergström A, Kull I, et al. Hand eczema and atopic dermatitis in adolescents: a prospective cohort study from the BAMSE project. Br J Dermatol. 2015 Nov;173(5):1175-82.

6 Ruff SM, Engebretsen KA, Zachariae C, Johansen JD, Silverberg JI, Egeberg A, et al. The association between atopic dermatitis and hand eczema: a systematic review and metaanalysis. Br J Dermatol. 2018 Apr;178(4): 879-88.

7 Vachiramon V, Tey HL, Thompson AE, Yosipovitch G. Atopic dermatitis in African American children: addressing unmet needs of a common disease. Pediatr Dermatol. 2012 Jul-Aug;29(4):395-402.

8 Noda S, Suárez-Fariñas M, Ungar B, Kim SJ, de Guzman Strong C, Xu H, et al. The Asian atopic dermatitis phenotype combines features of atopic dermatitis and psoriasis with increased TH17 polarization. J Allergy Clin Immunol. 2015 Nov;136(5):1254-64.
9 Simpson EL, Villarreal M, Jepson B, Rafaels N, David G, Hanifin J, et al. Patients with Atopic Dermatitis Colonized with Staphylococcus aureus Have a Distinct Phenotype and Endotype. J Invest Dermatol. 2018 Oct; 138(10):2224-33.

10 Schmitt J, Spuls PI, Thomas KS, Simpson E, Furue M, Deckert S, et al.; HOME initiative collaborators. The Harmonising Outcome Measures for Eczema (HOME) statement to assess clinical signs of atopic eczema in trials. J Allergy Clin Immunol. 2014 Oct;134(4): 800-7.

11 Stalder JF, Barbarot S, Wollenberg A, Holm EA, De Raeve L, Seidenari S, et al.; PO-SCORAD Investigators Group. Patient-Oriented SCORAD (PO-SCORAD): a new self-assessment scale in atopic dermatitis validated in Europe. Allergy. 2011 Aug;66(8):1114-21.

12 Gerbens LA, Prinsen CA, Chalmers JR, Drucker AM, von Kobyletzki LB, Limpens J, et al.; Harmonising Outcome Measures for Eczema (HOME) initiative. Evaluation of the measurement properties of symptom measurement instruments for atopic eczema: a systematic review. Allergy. 2017 Jan;72(1): 146-63.

13 Meng J, Steinhoff M. Molecular mechanisms of pruritus. Curr Res Transl Med. 2016 Oct Dec;64(4):203-6.

14 Rossbach K, Nassenstein C, Gschwandtner M, Schnell D, Sander K, Seifert R, et al. Histamine $\mathrm{H} 1, \mathrm{H} 3$ and $\mathrm{H} 4$ receptors are involved in pruritus. Neuroscience. 2011 Sep;190:89102.

15 Sonkoly E, Muller A, Lauerma AI, Pivarcsi A, Soto H, Kemeny L, et al. IL-31: a new link between $\mathrm{T}$ cells and pruritus in atopic skin inflammation. J Allergy Clin Immunol. 2006 Feb;117(2):411-7.

16 Kunsleben N, Rüdrich U, Gehring M, Novak N, Kapp A, Raap U. IL-31 Induces Chemotaxis, Calcium Mobilization, Release of Reactive Oxygen Species, and CCL26 in Eosinophils, Which Are Capable to Release IL-31. J Invest Dermatol. 2015 Jul;135(7):1908-11.
17 Petra AI, Tsilioni I, Taracanova A, KatsarouKatsari A, Theoharides TC. Interleukin 33 and interleukin 4 regulate interleukin 31 gene expression and secretion from human laboratory of allergic diseases 2 mast cells stimulated by substance $\mathrm{P}$ and/or immunoglobulin $\mathrm{E}$. Allergy Asthma Proc. 2018 Mar;39(2):153-60.

18 Feld M, Garcia R, Buddenkotte J, Katayama S, Lewis K, Muirhead G, et al. The pruritus- and TH2-associated cytokine IL-31 promotes growth of sensory nerves. J Allergy Clin Immunol. 2016 Aug;138(2):500-508.e24.

19 Tobin D, Nabarro G, Baart de la Faille H, van Vloten WA, van der Putte SC, Schuurman HJ. Increased number of immunoreactive nerve fibers in atopic dermatitis. J Allergy Clin Immunol. 1992 Oct;90(4 Pt 1):613-22.

20 Zar HJ, Ehrlich RI, Workman L, Weinberg EG. The changing prevalence of asthma, allergic rhinitis and atopic eczema in African adolescents from 1995 to 2002. Pediatr Allergy Immunol. 2007 Nov; 18(7):560-5.

21 Odhiambo JA, Williams HC, Clayton TO, Robertson CF, Asher MI; ISAAC Phase Three Study Group. Global variations in prevalence of eczema symptoms in children from ISAAC Phase Three. J Allergy Clin Immunol. 2009 Dec;124(6):1251-8.e23.

22 Garmhausen D, Hagemann T, Bieber T, Dimitriou I, Fimmers R, Diepgen T, et al. Characterization of different courses of atopic dermatitis in adolescent and adult patients. $\mathrm{Al}$ lergy. 2013 Apr;68(4):498-506.

23 Yaghmaie P, Koudelka CW, Simpson EL. Mental health comorbidity in patients with atopic dermatitis. J Allergy Clin Immunol. 2013 Feb;131(2):428-33.

24 Silverberg JI. Selected comorbidities of atopic dermatitis: Atopy, neuropsychiatric, and musculoskeletal disorders. Clin Dermatol. 2017 Jul - Aug;35(4):360-6.

25 Silverberg JI, Simpson EL. Association between severe eczema in children and multiple comorbid conditions and increased healthcare utilization. Pediatr Allergy Immunol. 2013 Aug;24(5):476-86. 
26 Simpson EL, Bieber T, Eckert L, Wu R, Ardeleanu M, Graham NM, et al. Patient burden of moderate to severe atopic dermatitis $(\mathrm{AD})$ : insights from a phase $2 \mathrm{~b}$ clinical trial of dupilumab in adults. J Am Acad Dermatol. 2016 Mar;74(3):491-8.

27 Schmitt J, Chen CM, Apfelbacher C, Romanos M, Lehmann I, Herbarth O, et al.; LISAplus Study Group. Infant eczema, infant sleeping problems, and mental health at 10 years of age: the prospective birth cohort study LISAplus. Allergy. 2011 Mar;66(3): 404-11.

28 Romanos M, Gerlach M, Warnke A, Schmitt J. Association of attention-deficit/hyperactivity disorder and atopic eczema modified by sleep disturbance in a large population-based sample. J Epidemiol Community Health. 2010 Mar;64(3):269-73.

29 Schmitt J, Buske-Kirschbaum A, Tesch F, Trikojat K, Stephan V, Abraham S, et al. Increased attention-deficit/hyperactivity symptoms in atopic dermatitis are associated with history of antihistamine use. Allergy. 2018 Mar;73(3):615-26.

30 Billeci L, Tonacci A, Tartarisco G, Ruta L, Pioggia G, Gangemi S. Association Between Atopic Dermatitis and Autism Spectrum Disorders: A Systematic Review. Am J Clin Dermatol. 2015 Oct; 16(5):371-88.

31 Eckert L, Gupta S, Amand C, Gadkari A, Mahajan P, Gelfand JM. Impact of atopic dermatitis on health-related quality of life and productivity in adults in the United States: An analysis using the National Health and Wellness Survey. J Am Acad Dermatol. 2017 Aug; 77(2):274-279.e3.

32 Dieris-Hirche J, Gieler U, Kupfer JP, Milch WE. Suicidal ideation, anxiety and depression in adult patients with atopic dermatitis. Hautarzt. 2009 Aug;60(8):641-6.

33 Lee S, Shin A. Association of atopic dermatitis with depressive symptoms and suicidal behaviors among adolescents in Korea: the 2013 Korean Youth Risk Behavior Survey. BMC Psychiatry. 2017 Jan;17(1):3.

34 Chang HY, Suh DI, Yang SI, Kang MJ, Lee SY, Lee E, et al. Prenatal maternal distress affects atopic dermatitis in offspring mediated by oxidative stress. J Allergy Clin Immunol. 2016 Aug;138(2):468-475.e5.

35 Egeberg A, Andersen YM, Gislason GH, Skov L, Thyssen JP. Prevalence of comorbidity and associated risk factors in adults with atopic dermatitis. Allergy. 2017 May;72(5): 783-91.

36 Drucker AM, Li WQ, Cho E, Li T, Sun Q, Camargo CA Jr, et al. Atopic dermatitis is not independently associated with nonfatal myocardial infarction or stroke among US women. Allergy. 2016 Oct;71(10):1496-500.

37 Silverberg JI, Greenland P. Eczema and cardiovascular risk factors in 2 US adult population studies. J Allergy Clin Immunol. 2015 Mar;135(3):721-8.e6.

38 Andersen YM, Egeberg A, Gislason GH, Hansen PR, Skov L, Thyssen JP. Risk of myocar- dial infarction, ischemic stroke, and cardiovascular death in patients with atopic dermatitis. J Allergy Clin Immunol. 2016 Jul;138(1): 310-312.e3.

39 Legendre L, Barnetche T, Mazereeuw-Hautier J, Meyer N, Murrell D, Paul C. Risk of lymphoma in patients with atopic dermatitis and the role of topical treatment: A systematic review and meta-analysis. J Am Acad Dermatol. 2015 Jun;72(6):992-1002.

40 Simpson EL, Guttman-Yassky E, Margolis DJ, Feldman SR, Qureshi A, Hata T, et al. Association of Inadequately Controlled Disease and Disease Severity With Patient-Reported Disease Burden in Adults With Atopic Dermatitis. JAMA Dermatol. 2018 Aug;154(8): 903-12.

41 Adamson AS. The economics burden of atopic dermatitis. Adv Exp Med Biol. 2017;1027: 79-92.

42 Nørreslet LB, Ebbehøj NE, Ellekilde Bonde JP, Thomsen SF, Agner T. The impact of atopic dermatitis on work life - a systematic review. J Eur Acad Dermatol Venereol. 2018 Jan;32(1):23-38

43 Apfelbacher CJ, Diepgen TL, Schmitt J. Determinants of eczema: population-based cross-sectional study in Germany. Allergy. 2011 Feb;66(2):206-13.

44 Thomsen SF, Ulrik CS, Kyvik KO, Hjelmborg J, Skadhauge LR, Steffensen I, et al. Importance of genetic factors in the etiology of atopic dermatitis: a twin study. Allergy Asthma Proc. 2007 Sep-Oct;28(5):535-9.

45 Palmer CN, Irvine AD, Terron-Kwiatkowski A, Zhao Y, Liao H, Lee SP, et al. Common loss-of-function variants of the epidermal barrier protein filaggrin are a major predisposing factor for atopic dermatitis. Nat Genet. 2006 Apr;38(4):441-6.

46 Weidinger S, Willis-Owen SA, Kamatani Y, Baurecht $\mathrm{H}$, Morar N, Liang L, et al. A genome-wide association study of atopic dermatitis identifies loci with overlapping effects on asthma and psoriasis. Hum Mol Genet. 2013 Dec;22(23):4841-56

47 Paternoster L, Standl M, Waage J, Baurecht H, Hotze M, Strachan DP, et al.; Australian Asthma Genetics Consortium (AAGC). Multi-ancestry genome-wide association study of 21,000 cases and 95,000 controls identifies new risk loci for atopic dermatitis. Nat Genet. 2015 Dec;47(12):1449-56.

48 Ferreira MA, Vonk JM, Baurecht H, Marenholz I, Tian C, Hoffman JD, et al.; 23andMe Research Team; collaborators of the SHARE study. Eleven loci with new reproducible genetic associations with allergic disease risk. J Allergy Clin Immunol. 2018. doi: 10.1016/j. jaci.2018.03.012.

49 Thürmann L, Grützmann K, Klös M, Bieg M, Winter M, Polte T, et al. Early-onset childhood atopic dermatitis is related to NLRP2 repression. J Allergy Clin Immunol. 2018 Apr;141(4):1482-1485.e16.

50 Kubo A, Nagao K, Amagai M. Epidermal barrier dysfunction and cutaneous sensitization in atopic diseases. J Clin Invest. $2012 \mathrm{Feb}$; 122(2):440-7.

51 Eberlein-König B, Schäfer T, Huss-Marp J, Darsow U, Möhrenschlager M, Herbert O, et al. Skin surface $\mathrm{pH}$, stratum corneum hydration, trans-epidermal water loss and skin roughness related to atopic eczema and skin dryness in a population of primary school children. Acta Derm Venereol. 2000 May; 80(3):188-91.

52 Engebretsen KA, Bandier J, Kezic S, Riethmüller C, Heegaard NH, Carlsen BC, et al. Concentration of filaggrin monomers, its metabolites and corneocyte surface texture in individuals with a history of atopic dermatitis and controls. J Eur Acad Dermatol Venereol. 2018 May;32(5):796-804.

53 McAleer MA, Irvine AD. The multifunctional role of filaggrin in allergic skin disease. $\mathrm{J} \mathrm{Al}$ lergy Clin Immunol. 2013 Feb;131(2):280-91.

54 Smith FJ, Irvine AD, Terron-Kwiatkowski A, Sandilands A, Campbell LE, Zhao Y, et al. Loss-of-function mutations in the gene encoding filaggrin cause ichthyosis vulgaris. Nat Genet. 2006 Mar;38(3):337-42.

55 Brown SJ, Relton CL, Liao H, Zhao Y, Sandilands A, Wilson IJ, et al. Filaggrin null mutations and childhood atopic eczema: a population-based case-control study. J Allergy Clin Immunol. 2008 Apr;121(4):940-46.e3.

56 Thyssen JP, Carlsen BC, Bisgaard H, Giwercman C, Johansen JD, Linneberg A, et al. Individuals who are homozygous for the 2282del4 and R501X filaggrin null mutations do not always develop dermatitis and complete long-term remission is possible. J Eur Acad Dermatol Venereol. 2012 Mar; 26(3):386-9.

57 Howell MD, Kim BE, Gao P, Grant AV, Boguniewicz M, Debenedetto A, et al. Cytokine modulation of atopic dermatitis filaggrin skin expression. J Allergy Clin Immunol. 2007 Jul; 120(1):150-5.

58 Seltmann J, Roesner LM, von Hesler FW, Wittmann M, Werfel T. IL-33 impacts on the skin barrier by downregulating the expression of filaggrin. J Allergy Clin Immunol. 2015 Jun; 135(6):1659-61.e4

59 Pendaries V, Malaisse J, Pellerin L, Le Lamer M, Nachat R, Kezic S, et al. Knockdown of filaggrin in a three-dimensional reconstructed human epidermis impairs keratinocyte differentiation. J Invest Dermatol. 2014 Dec: 134(12):2938-46.

60 Nakai K, Yoneda K, Hosokawa Y, Moriue T, Presland RB, Fallon PG, et al. Reduced expression of epidermal growth factor receptor, E-cadherin, and occludin in the skin of flaky tail mice is due to filaggrin and loricrin deficiencies. Am J Pathol. 2012 Sep;181(3):96977.

61 Wang XW, Wang JJ, Gutowska-Owsiak D, Salimi M, Selvakumar TA, Gwela A, et al. Deficiency of filaggrin regulates endogenous cysteine protease activity, leading to impaired skin barrier function. Clin Exp Dermatol. 2017 Aug;42(6):622-31. 
62 Lee KH, Cho KA, Kim JY, Kim JY, Baek JH, Woo SY, et al. Filaggrin knockdown and Tolllike receptor 3 (TLR3) stimulation enhanced the production of thymic stromal lymphopoietin (TSLP) from epidermal layers. Exp Dermatol. 2011 Feb;20(2):149-51.

63 Janssens M, van Smeden J, Gooris GS, Bras W, Portale G, Caspers PJ, et al. Lamellar lipid organization and ceramide composition in the stratum corneum of patients with atopic eczema. J Invest Dermatol. 2011 Oct;131(10): $2136-8$.

64 Jungersted JM, Scheer H, Mempel M, Baurecht $\mathrm{H}$, Cifuentes L, Høgh JK, et al. Stratum corneum lipids, skin barrier function and filaggrin mutations in patients with atopic eczema. Allergy. 2010 Jul;65(7):911-8.

65 Ishikawa J, Narita H, Kondo N, Hotta M, Takagi Y, Masukawa Y, et al. Changes in the ceramide profile of atopic dermatitis patients. J Invest Dermatol. 2010 Oct;130(10):2511-4.

66 Danso MO, van Drongelen V, Mulder A, van Esch J, Scott H, van Smeden J, et al. TNF-a and Th2 cytokines induce atopic dermatitislike features on epidermal differentiation proteins and stratum corneum lipids in human skin equivalents. J Invest Dermatol. 2014 Jul; 134(7):1941-50.

67 Roedl D, Traidl-Hoffmann C, Ring J, Behrendt $\mathrm{H}$, Braun-Falco $M$. Serine protease inhibitor lymphoepithelial Kazal type-related inhibitor tends to be decreased in atopic dermatitis. J Eur Acad Dermatol Venereol. 2009 Nov;23(11):1263-6.

68 Briot A, Lacroix M, Robin A, Steinhoff M, Deraison $\mathrm{C}$, Hovnanian A. Par2 inactivation inhibits early production of TSLP, but not cutaneous inflammation, in Netherton syndrome adult mouse model. J Invest Dermatol. 2010 Dec;130(12):2736-42.

69 Fortugno P, Furio L, Teson M, Berretti M, El Hachem M, Zambruno G, et al. The $420 \mathrm{~K}$ LEKTI variant alters LEKTI proteolytic activation and results in protease deregulation: implications for atopic dermatitis. Hum $\mathrm{Mol}$ Genet. 2012 Oct;21(19):4187-200.

70 Zhu Y, Underwood J, Macmillan D, Shariff L, O'Shaughnessy R, Harper JI, et al. Persistent kallikrein 5 activation induces atopic dermatitis-like skin architecture independent of PAR2 activity. J Allergy Clin Immunol. 2017 Nov; 140(5):1310-1322.e5.

71 Kezic S, Novak N, Jakasa I, Jungersted JM, Simon M, Brandner JM, et al. Skin barrier in atopic dermatitis. Front Biosci. 2014 Jan; 19(3):542-56.

72 Kirschner N, Rosenthal R, Furuse M, Moll I, Fromm M, Brandner JM. Contribution of tight junction proteins to ion, macromolecule, and water barrier in keratinocytes. J Invest Dermatol. 2013 May;133(5):1161-9.

73 De Benedetto A, Rafaels NM, McGirt LY, Ivanov AI, Georas SN, Cheadle C, Berger AE, Zhang K, Vidyasagar S, Yoshida T, Boguniewicz M, Hata T, Schneider LC, Hanifin JM, Gallo RL, Novak N, Weidinger S, Beaty TH, Leung DY, Barnes KC, Beck LA. Tight junc- tion defects in patients with atopic dermatitis. J Allergy Clin Immunol. 2011 Mar;127(3): 773-86.e1-7.

74 Hirasawa Y, Takai T, Nakamura T, Mitsuishi K, Gunawan H, Suto H, et al. Staphylococcus aureus extracellular protease causes epidermal barrier dysfunction. J Invest Dermatol. 2010 Feb;130(2):614-7.

75 Nakamura T, Hirasawa Y, Takai T, Mitsuishi K, Okuda M, Kato T, et al. Reduction of skin barrier function by proteolytic activity of a recombinant house dust mite major allergen Der f 1. J Invest Dermatol. 2006 Dec;126(12): 2719-23.

76 Bruynzeel-Koomen C, van der Donk EM, Bruynzeel PL, Capron M, de Gast GC, Mudde GC. Associated expression of CD1 antigen and $\mathrm{Fc}$ receptor for IgE on epidermal Langerhans cells from patients with atopic dermatitis. Clin Exp Immunol. 1988 Oct;74(1):137-42.

77 Bieber T, Kraft S, Jürgens M, Strobel I, Haberstok J, Tomov H, et al. New insights in the structure and biology of the high affinity receptor for IgE (Fc epsilon RI) on human epidermal Langerhans cells. J Dermatol Sci. 1996 Oct;13(1):71-5

78 Wollenberg A, Kraft S, Hanau D, Bieber T. Immunomorphological and ultrastructural characterization of Langerhans cells and a novel, inflammatory dendritic epidermal cell (IDEC) population in lesional skin of atopic eczema. J Invest Dermatol. 1996 Mar;106(3): 446-53.

79 Kubo A, Nagao K, Yokouchi M, Sasaki H, Amagai M. External antigen uptake by Langerhans cells with reorganization of epidermal tight junction barriers. J Exp Med. 2009 Dec; 206(13):2937-46.

80 Yoshida K, Kubo A, Fujita H, Yokouchi M, Ishii K, Kawasaki H, et al. Distinct behavior of human Langerhans cells and inflammatory dendritic epidermal cells at tight junctions in patients with atopic dermatitis. J Allergy Clin Immunol. 2014 Oct;134(4):856-64.

81 Kinoshita H, Takai T, Le TA, Kamijo S, Wang $\mathrm{XL}$, Ushio $\mathrm{H}$, et al. Cytokine milieu modulates release of thymic stromal lymphopoietin from human keratinocytes stimulated with double-stranded RNA. J Allergy Clin Immunol. 2009 Jan;123(1):179-86.

82 Vu AT, Baba T, Chen X, Le TA, Kinoshita H, Xie $Y$, et al. Staphylococcus aureus membrane and diacylated lipopeptide induce thymic stromal lymphopoietin in keratinocytes through the Toll-like receptor 2-Toll-like receptor 6 pathway. J Allergy Clin Immunol. 2010 Nov;126(5):985-93.

83 Jang YH, Choi JK, Jin M, Choi YA, Ryoo ZY, Lee HS, et al. House Dust Mite Increases proTh2 Cytokines IL-25 and IL-33 via the Activation of TLR1/6 Signaling. J Invest Dermatol. 2017 Nov;137(11):2354-61.

84 Kato T, Takai T, Fujimura T, Matsuoka H, Ogawa T, Murayama K, et al. Mite serine protease activates protease-activated receptor- 2 and induces cytokine release in human keratinocytes. Allergy. 2009 Sep;64(9):1366-74.
85 Roth SA, Simanski M, Rademacher F, Schröder L, Harder J. The pattern recognition receptor NOD2 mediates Staphylococcus aureus-induced IL-17C expression in keratinocytes. J Invest Dermatol. 2014 Feb;134(2):374-80.

86 Oyoshi MK, Larson RP, Ziegler SF, Geha RS Mechanical injury polarizes skin dendritic cells to elicit a $\mathrm{T}(\mathrm{H}) 2$ response by inducing cutaneous thymic stromal lymphopoietin expression. J Allergy Clin Immunol. 2010 Nov; 126(5):976-84.

87 Savinko T, Matikainen S, Saarialho-Kere U, Lehto $M$, Wang G, Lehtimäki S, et al. IL-33 and ST2 in atopic dermatitis: expression profiles and modulation by triggering factors. J Invest Dermatol. 2012 May;132(5):1392-400.

88 Watanabe S, Kano R, Sato H, Nakamura Y, Hasegawa A. The effects of Malassezia yeasts on cytokine production by human keratinocytes. J Invest Dermatol. 2001 May;116(5): 769-73.

89 Wollenberg A, Wen S, Bieber T. Phenotyping of epidermal dendritic cells: clinical applications of a flow cytometric micromethod. Cytometry. 1999 Oct;37(2):147-55.

90 Suárez-Fariñas M, Tintle SJ, Shemer A, Chiricozzi A, Nograles K, Cardinale I, et al. Nonlesional atopic dermatitis skin is characterized by broad terminal differentiation defects and variable immune abnormalities. J Allergy Clin Immunol. 2011 Apr;127(4):954-64.e1.

91 Akdis M, Akdis CA, Weigl L, Disch R, Blaser K. Skin-homing, CLA+ memory $\mathrm{T}$ cells are activated in atopic dermatitis and regulate $\mathrm{IgE}$ by an IL-13-dominated cytokine pattern: IgG4 counter-regulation by CLA- memory T cells. J Immunol. 1997 Nov;159(9):4611-9.

92 Soumelis V, Reche PA, Kanzler H, Yuan W, Edward G, Homey B, et al. Human epithelial cells trigger dendritic cell mediated allergic inflammation by producing TSLP. Nat Immunol. 2002 Jul;3(7):673-80.

93 Pivarcsi A, Gombert M, Dieu-Nosjean MC, Lauerma A, Kubitza R, Meller S, et al. CC chemokine ligand 18 , an atopic dermatitis-associated and dendritic cell-derived chemokine, is regulated by staphylococcal products and allergen exposure. J Immunol. 2004 Nov; 173(9):5810-7.

94 Giustizieri ML, Mascia F, Frezzolini A, De Pità $\mathrm{O}$, Chinni LM, Giannetti A, et al. Keratinocytes from patients with atopic dermatitis and psoriasis show a distinct chemokine production profile in response to $\mathrm{T}$ cell-derived cytokines. J Allergy Clin Immunol. 2001 May; 107(5):871-7.

95 Wang YH, Angkasekwinai P, Lu N, Voo KS, Arima K, Hanabuchi S, et al. IL-25 augments type 2 immune responses by enhancing the expansion and functions of TSLP-DC-activated Th2 memory cells. J Exp Med. 2007 Aug;204(8):1837-47.

96 Islam SA, Chang DS, Colvin RA, Byrne MH, McCully ML, Moser B, et al. Mouse CCL8, a CCR8 agonist, promotes atopic dermatitis by recruiting IL-5+ T(H)2 cells. Nat Immunol. 2011 Feb;12(2):167-77. 
97 Kubo A, Nagao K, Yokouchi M, Sasaki H, Amagai M. External antigen uptake by Langerhans cells with reorganization of epidermal tight junction barriers. J Exp Med. 2009 Dec;206(13):2937-46.

98 Zheng T, Oh MH, Oh SY, Schroeder JT, Glick AB, Zhu Z. Transgenic expression of interleukin-13 in the skin induces a pruritic dermatitis and skin remodeling. J Invest Dermatol. 2009 Mar;129(3):742-51.

99 Schmid-Grendelmeier P, Altznauer F, Fischer B, Bizer C, Straumann A, Menz G, et al. Eosinophils express functional IL-13 in eosinophilic inflammatory diseases. J Immunol. 2002 Jul;169(2):1021-7.

100 Punnonen J, Yssel H, de Vries JE. The relative contribution of IL-4 and IL-13 to human IgE synthesis induced by activated CD4+ or CD8+ T cells. J Allergy Clin Immunol. 1997 Dec;100(6 Pt 1):792-801.

101 Herrick CA, Xu L, McKenzie AN, Tigelaar RE, Bottomly K. IL-13 is necessary, not simply sufficient, for epicutaneously induced Th2 responses to soluble protein antigen. J Immunol. 2003 Mar;170(5):2488-95.

102 Imai Y, Yasuda K, Sakaguchi Y, Haneda T, Mizutani H, Yoshimoto T, et al. Skin-specific expression of IL-33 activates group 2 innate lymphoid cells and elicits atopic dermatitis-like inflammation in mice. Proc Natl Acad Sci USA. 2013 Aug; 110(34): 13921-6.

103 Simon D, Lindberg RL, Kozlowski E, Braathen LR, Simon HU. Epidermal caspase-3 cleavage associated with interferon-gammaexpressing lymphocytes in acute atopic dermatitis lesions. Exp Dermatol. 2006 Jun; 15(6):441-6.

104 Eyerich K, Pennino D, Scarponi C, Foerster S, Nasorri F, Behrendt H, et al. IL-17 in atopic eczema: linking allergen-specific adaptive and microbial-triggered innate immune response. J Allergy Clin Immunol. 2009 Jan; 123(1):59-66.e4.

105 Nograles KE, Zaba LC, Shemer A, FuentesDuculan J, Cardinale I, Kikuchi T, et al. IL22-producing "T22" $\mathrm{T}$ cells account for upregulated IL-22 in atopic dermatitis despite reduced IL-17-producing TH17 T cells. J Allergy Clin Immunol. 2009 Jun;123(6):124452.e2.

106 Simon D, Aeberhard C, Erdemoglu Y, Simon HU. Th17 cells and tissue remodeling in atopic and contact dermatitis. Allergy. 2014 Jan;69(1):125-31.

107 Noda S, Suárez-Fariñas M, Ungar B, Kim SJ, de Guzman Strong C, Xu H, et al. The Asian atopic dermatitis phenotype combines features of atopic dermatitis and psoriasis with increased TH17 polarization. J Allergy Clin Immunol. 2015 Nov;136(5):1254-64.

108 Brunner PM, Israel A, Zhang N, Leonard A, Wen HC, Huynh T, et al. Early-onset pediatric atopic dermatitis is characterized by TH2/TH17/TH22-centered inflammation and lipid alterations. J Allergy Clin Immunol. 2018 Jun;141(6):2094-106.
109 Kong HH, Oh J, Deming C, Conlan S, Grice EA, Beatson MA, et al.; NISC Comparative Sequence Program. Temporal shifts in the skin microbiome associated with disease flares and treatment in children with atopic dermatitis. Genome Res. 2012 May;22(5): 850-9.

110 Kennedy EA, Connolly J, Hourihane JO, Fallon PG, McLean WH, Murray D, et al. Skin microbiome before development of atopic dermatitis: early colonization with commensal staphylococci at 2 months is associated with a lower risk of atopic dermatitis at 1 year. J Allergy Clin Immunol. 2017 Jan;139(1):166-72.

111 Kobayashi T, Glatz M, Horiuchi K, Kawasaki H, Akiyama H, Kaplan DH, et al. Dysbiosis and Staphylococcus aureus Colonization Drives Inflammation in Atopic Dermatitis. Immunity. 2015 Apr;42(4): 756-66.

112 Geoghegan JA, Irvine AD, Foster TJ. Staphylococcus aureus and Atopic Dermatitis: A Complex and Evolving Relationship. Trends Microbiol. 2018 Jun;26(6):484-97.

113 Nakatsuji T, Chen TH, Two AM, Chun KA, Narala S, Geha RS, et al. Staphylococcus aureus Exploits Epidermal Barrier Defects in Atopic Dermatitis to Trigger Cytokine Expression. J Invest Dermatol. 2016 Nov; 136(11):2192-200.

114 Bunikowski R, Mielke ME, Skarabis H, Worm M, Anagnostopoulos I, Kolde G, et al. Evidence for a disease-promoting effect of Staphylococcus aureus-derived exotoxins in atopic dermatitis. J Allergy Clin Immunol. 2000 Apr;105(4):814-9.

115 Meylan P, Lang C, Mermoud S, Johannsen A, Norrenberg S, Hohl D, et al. Skin Colonization by Staphylococcus aureus Precedes the Clinical Diagnosis of Atopic Dermatitis in Infancy. J Invest Dermatol. 2017 Dec; 137(12):2497-504.

116 Simon D, Marti H, Heer P, Simon HU, Braathen LR, Straumann A. Eosinophilic esophagitis is frequently associated with IgE-mediated allergic airway diseases. J Allergy Clin Immunol. 2005 May;115(5):1090-2.

117 Weidinger S, O'Sullivan M, Illig T, Baurecht H, Depner M, Rodriguez E, et al. Filaggrin mutations, atopic eczema, hay fever, and asthma in children. J Allergy Clin Immunol. 2008 May;121(5):1203-1209.e1.

118 Brown SJ, Asai Y, Cordell HJ, Campbell LE, Zhao Y, Liao H, et al. Loss-of-function variants in the filaggrin gene are a significant risk factor for peanut allergy. J Allergy Clin Immunol. 2011 Mar;127(3):661-7.

119 Flohr C, Perkin M, Logan K, Marrs T, Radulovic S, Campbell LE, et al. Atopic dermatitis and disease severity are the main risk factors for food sensitization in exclusively breastfed infants. J Invest Dermatol. 2014 Feb; 134(2):345-50.

120 Noti M, Kim BS, Siracusa MC, Rak GD, Kubo M, Moghaddam AE, et al. Exposure to food allergens through inflamed skin pro- motes intestinal food allergy through the thymic stromal lymphopoietin-basophil axis. J Allergy Clin Immunol. 2014 May; 133(5):1390-9.

121 Johansson EK, Bergström A, Kull I, Lind T, Söderhäll C, van Hage M, et al. IgE sensitization in relation to preschool eczema and filaggrin mutation. J Allergy Clin Immunol. 2017 Dec;140(6):1572-1579.e5.

122 Akdis CA, Akdis M, Simon D, Dibbert B, Weber M, Gratzl S, et al. T cells and T cellderived cytokines as pathogenic factors in the nonallergic form of atopic dermatitis. J Invest Dermatol. 1999 Oct;113(4):628-34.

123 Eller E, Kjaer HF, Høst A, Andersen KE, Bindslev-Jensen C. Food allergy and food sensitization in early childhood: results from the DARC cohort. Allergy. 2009 Jul;64(7): 1023-9.

124 Eigenmann PA, Sicherer SH, Borkowski TA, Cohen BA, Sampson HA. Prevalence of IgEmediated food allergy among children with atopic dermatitis. Pediatrics. 1998 Mar; 101(3):E8

125 Wolkerstorfer A, Wahn U, Kjellman NI, Diepgen TL, De Longueville M, Oranje AP. Natural course of sensitization to cow's milk and hen's egg in childhood atopic dermatitis: ETAC study group. Clin Exp Allergy. 2002 Jan;32(1):70-3.

126 Schäfer T, Böhler E, Ruhdorfer S, Weigl L, Wessner D, Heinrich J, et al. Epidemiology of food allergy/food intolerance in adults: associations with other manifestations of atopy. Allergy. 2001 Dec;56(12):1172-9.

127 Werfel T, Ahlers G, Schmidt P, Boeker M, Kapp A, Neumann C. Milk-responsive atopic dermatitis is associated with a casein-specific lymphocyte response in adolescent and adult patients. J Allergy Clin Immunol. 1997 Jan;99(1 Pt 1):124-33.

128 Reekers R, Busche M, Wittmann M, Kapp A, Werfel T. Birch pollen-related foods trigger atopic dermatitis in patients with specific cutaneous T-cell responses to birch pollen antigens. J Allergy Clin Immunol. 1999 Aug; 104(2 Pt 1):466-72.

129 Longo G, Berti I, Burks AW, Krauss B, Barbi E. IgE-mediated food allergy in children. Lancet. 2013 Nov;382(9905):1656-64.

130 Wassmann-Otto A, Heratizadeh A, Wichmann K, Werfel T. Birch pollen-related foods can cause late eczematous reactions in patients with atopic dermatitis. Allergy. 2018 Oct;73(10):2046-54.

131 Brough HA, Simpson A, Makinson K, Hankinson J, Brown S, Douiri A, et al. Peanut allergy: effect of environmental peanut exposure in children with filaggrin loss-offunction mutations. J Allergy Clin Immunol. 2014 Oct;134(4):867-875.e1.

132 Brough HA, Liu AH, Sicherer S, Makinson K, Douiri A, Brown SJ, et al. Atopic dermatitis increases the effect of exposure to peanut antigen in dust on peanut sensitization and likely peanut allergy. J Allergy Clin Immunol. 2015 Jan;135(1):164-70. 
133 Du Toit G, Roberts G, Sayre PH, Bahnson HT, Radulovic S, Santos AF, et al.; LEAP Study Team. Randomized trial of peanut consumption in infants at risk for peanut allergy. $\mathrm{N}$ Engl J Med. 2015 Feb;372(9):803-13.

134 Ierodiakonou D, Garcia-Larsen V, Boyle RJ. Allergenic Food Introduction and Childhood Risk of Allergic or Autoimmune Disease-Reply. JAMA. 2017 Jan;317(1):87.

135 Wollenberg A, Barbarot S, Bieber T, Christen-Zaech S, Deleuran M, Fink-Wagner A, et al.; European Dermatology Forum (EDF), the European Academy of Dermatology and Venereology (EADV), the European Academy of Allergy and Clinical Immunology (EAACI), the European Task Force on Atopic Dermatitis (ETFAD), European Federation of Allergy and Airways Diseases Patients' Associations (EFA), the European Society for Dermatology and Psychiatry (ESDaP), the European Society of Pediatric Dermatology (ESPD), Global Allergy and Asthma European Network (GA2LEN) and the European Union of Medical Specialists (UEMS). Consensus-based European guidelines for treatment of atopic eczema (atopic dermatitis) in adults and children: part I. J Eur Acad Dermatol Venereol. 2018 May; 32(5):657-82.

136 Wollenberg A, Barbarot S, Bieber T, Christen-Zaech S, Deleuran M, Fink-Wagner A, et al.; European Dermatology Forum (EDF), the European Academy of Dermatology and Venereology (EADV), the European Academy of Allergy and Clinical Immunology (EAACI), the European Task Force on Atopic Dermatitis (ETFAD), European Federation of Allergy and Airways Diseases Patients' Associations (EFA), the European Society for Dermatology and Psychiatry (ESDaP), the European Society of Pediatric Dermatology (ESPD), Global Allergy and Asthma European Network (GA2LEN) and the European Union of Medical Specialists (UEMS). Consensus-based European guidelines for treatment of atopic eczema (atopic dermatitis) in adults and children: part II. J Eur Acad Dermatol Venereol. 2018 Jun; 32(6):850-78.

137 van Zuuren EJ, Fedorowicz Z, Arents BW. Emollients and moisturizers for eczema: abridged Cochrane systematic review including GRADE assessments. Br J Dermatol. 2017 Nov;177(5):1256-71.

138 Simpson EL, Chalmers JR, Hanifin JM, Thomas KS, Cork MJ, McLean WH, et al. Emollient enhancement of the skin barrier from birth offers effective atopic dermatitis prevention. J Allergy Clin Immunol. 2014 Oct;134(4):818-23.

139 Horimukai K, Morita K, Narita M, Kondo M, Kitazawa H, Nozaki M, et al. Application of moisturizer to neonates prevents develop- ment of atopic dermatitis. J Allergy Clin Immunol. 2014 Oct;134(4):824-830.e6.

140 Wollenberg A, Reitamo S, Atzori F, Lahfa M, Ruzicka T, Healy E, et al.; European Tacrolimus Ointment Study Group. Proactive treatment of atopic dermatitis in adults with $0.1 \%$ tacrolimus ointment. Allergy. 2008 Jun;63(6):742-50.

141 Sigurgeirsson B, Boznanski A, Todd G, Vertruyen A, Schuttelaar ML, Zhu X, et al. Safety and efficacy of pimecrolimus in atopic dermatitis: a 5-year randomized trial. Pediatrics. 2015 Apr;135(4):597-606.

142 Mandelin JM, Remitz A, Virtanen HM, Malmberg LP, Haahtela T, Reitamo S. A 10year open follow-up of eczema and respiratory symptoms in patients with atopic dermatitis treated with topical tacrolimus for the first 4 years. J Dermatolog Treat. 2010 May;21(3):167-70.

143 Barbarot S, Stalder JF. Therapeutic patient education in atopic eczema. Br J Dermatol. 2014 Jul;170 Suppl 1:44-8.

144 Heratizadeh A, Werfel T, Wollenberg A, Abraham S, Plank-Habibi S, Schnopp C, et al.; Arbeitsgemeinschaft Neurodermitisschulung für Erwachsene (ARNE) Study Group. Effects of structured patient education in adults with atopic dermatitis: multicenter randomized controlled trial. J Allergy Clin Immunol. 2017 Sep;140(3):845-853.e3.

145 Simon D, Bieber T. Systemic therapy for atopic dermatitis. Allergy. 2014 Jan;69(1): 46-55.

146 Grahovac M, Molin S, Prinz JC, Ruzicka T, Wollenberg A. Treatment of atopic eczema with oral alitretinoin. Br J Dermatol. 2010 Jan;162(1):217-8.

147 Beck LA, Thaçi D, Hamilton JD, Graham NM, Bieber T, Rocklin R, et al. Dupilumab treatment in adults with moderate-to-severe atopic dermatitis. N Engl J Med. 2014 Jul; 371(2):130-9.

148 Simpson EL, Bieber T, Guttman-Yassky E, Beck LA, Blauvelt A, Cork MJ, et al.; SOLO 1 and SOLO 2 Investigators. Two Phase 3 Trials of Dupilumab versus Placebo in Atopic Dermatitis. N Engl J Med. 2016 Dec; 375(24):2335-48.

149 Blauvelt A, de Bruin-Weller M, Gooderham M, Cather JC, Weisman J, Pariser D, et al. Long-term management of moderate-to-severe atopic dermatitis with dupilumab and concomitant topical corticosteroids (LIBERTY AD CHRONOS): a 1-year, randomised, double-blinded, placebo-controlled, phase 3 trial. Lancet. 2017 Jun; 389(10086):2287-303.

150 Simpson EL, Flohr C, Eichenfield LF, Bieber T, Sofen H, Taïeb A, et al. Efficacy and safety of lebrikizumab (an anti-IL-13 monoclonal antibody) in adults with moderate-tosevere atopic dermatitis inadequately con- trolled by topical corticosteroids: A randomized, placebo-controlled phase II trial (TREBLE). J Am Acad Dermatol. 2018 May;78(5):863-871.e11.

151 Wollenberg A, Howell MD, Guttman-Yassky E, Silverberg JI, Kell C, Ranade K, et al. Treatment of atopic dermatitis with tralokinumab, an anti-IL-13 monoclonal antibody. J Allergy Clin Immunol. 2019 Jan; 143(1):135-41.

152 Guttman-Yassky E, Brunner PM, Neumann AU, Khattri S, Pavel AB, Malik K, et al. Efficacy and safety of fezakinumab (an IL-22 monoclonal antibody) in adults with moderate-to-severe atopic dermatitis inadequately controlled by conventional treatments: a randomized, double-blind, phase 2a trial. J Am Acad Dermatol. 2018 May;78(5):872-81.e6.

153 Khattri S, Brunner PM, Garcet S, Finney R, Cohen SR, Oliva M, et al. Efficacy and safety of ustekinumab treatment in adults with moderate-to-severe atopic dermatitis. Exp Dermatol. 2017 Jan;26(1):28-35.

154 Saeki H, Kabashima K, Tokura Y, Murata Y, Shiraishi A, Tamamura R, et al. Efficacy and safety of ustekinumab in Japanese patients with severe atopic dermatitis: a randomized, double-blind, placebo-controlled, phase II study. Br J Dermatol. 2017 Aug;177(2):41927.

155 Ruzicka T, Hanifin JM, Furue M, Pulka G Mlynarczyk I, Wollenberg A, et al.; XCIMA Study Group. Anti-interleukin-31 receptor A antibody for atopic dermatitis. $\mathrm{N}$ Engl J Med. 2017 Mar;376(9):826-35.

156 Bissonnette R, Papp KA, Poulin Y, Gooderham M, Raman M, Mallbris L, et al. Topical tofacitinib for atopic dermatitis: a phase IIa randomized trial. Br J Dermatol. 2016 Nov; 175(5):902-11.

157 Guttman-Yassky E, Silverberg JI, Nemoto O, Forman SB, Wilke A, Prescilla R, de la Peña A, Nunes FP, Janes J, Gamalo M, Donley D, Paik J, DeLozier AM, Nickoloff BJ, Simpson EL. Baricitinib in adult patients with moderate-to-severe atopic dermatitis: a phase 2 parallel, double-blinded, randomized placebo-controlled multiple-dose study. J Am Acad Dermatol. 2018. doi: 10.1016/j.jaad.2018.01.018.

158 Howell MD, Fitzsimons C, Smith PA. JAK/ STAT inhibitors and other small molecule cytokine antagonists for the treatment of allergic disease. Ann Allergy Asthma Immunol. 2018 Apr;120(4):367-75.

159 Paller AS, Tom WL, Lebwohl MG, Blumenthal RL, Boguniewicz M, Call RS, et al. Efficacy and safety of crisaborole ointment, a novel, nonsteroidal phosphodiesterase 4 (PDE4) inhibitor for the topical treatment of atopic dermatitis $(\mathrm{AD})$ in children and adults. J Am Acad Dermatol. 2016 Sep;75(3): 494-503.e6. 